\title{
Development of Group Counseling with Modeling Techniques to Increase Efficiency in Career Decisions of Students
}

\author{
Siti Mutmainah ${ }^{1 *}$, I Ketut Gading ${ }^{2}$, I Ketut Dharsana ${ }^{3}$ \\ 1,2,3 Universitas Pendidikan Ganesha \\ *Corresponding author, e-mail: $\underline{\text { Sitimutmainah101976@gmail.com }}$
}

Received August 02, 2021; Revised August 31, 2021; Accepted Sept. 20, 2021; Published Online 2021-10-01

\section{Conflict of Interest Disclosures:}

The authors declare that they have no significant competing financial, professional or personal interests that might have influenced the performance or presentation of the work described in this manuscript.

\begin{abstract}
This study aims to develop a guidebook for group counseling on modeling techniques to improve self-efficacy in career decision making for vocational students. This research is a type of research and development (R\&D). The research and development model of the 4D model consists of 4 stages, namely; define, design, develop, and disseminate. The product acceptance tester of this manual involves 5 experts and practitioners of guidance and counseling. Testing the validity of the content of the manual product using the Lawshe formula and testing the effectiveness by finding the effective contribution using the Cohen-D formula. The results of the acceptance test data analysis with the Lawshe CVR test obtained a value per item (CVR> 0 or 1$)$ for all items, then the results of the Lawshe CVI analysis obtained a score of 1 , then this result means that the value of the content validity of the product content of the group counseling guidebook Modeling technique is high, calculate the effectiveness of the guidebook and get the results 3.17 So based on the value of the effectiveness of the above then according to the criteria. If the value of effect size $>0.50$ then the group counseling guide modeling technique is effective to minimize self-efficacy students' in making career decisions. This shows that the level of effectiveness of the modeling technique group counseling guidebook for SMK students is very good, so it is important to develop it for students in SMK.
\end{abstract}

Keywords: research and develoment, self-efficacy, career decisions.

\section{Introduction}

The role of students in making the right career decisions requires a long process or time. Because most of the students have difficulty in making choices about their career decisions. (Nadiana, 2014) states that career maturity is an individual's success in completing typical career development tasks atstages of career development certain. Indications that are relevant to career maturity are the ability to make plans, willingness to assume responsibility, and awareness of all internal and external factors that must be considered in making job choices or establishing themselves in a job. However, to be able to make the right career decisions, students need confidence in the choices according to their abilities. This belief is what Bandura calls selfefficacy. 
Bandura (in Kurniasari et al., 2018) says that self-efficacy is basically the result of cognitive processes in the form of decisions, beliefs, or awards about the extent to which individuals estimate their abilities to carry out certain tasks or actions needed to achieve the desired results. Self-efficacy is not related to the skills possessed, but is related to the individual's beliefs about what can be done with the skills he has no matter how big. Self-efficacy emphasizes the component of self-confidence that a person has in dealing with future situations that are ambiguous, unpredictable, and often stressful. Self-efficacy will affect several aspects of one's cognition and behavior. Self-efficacy, which is related to an individual's belief in his ability to carry out his duties in career selection and planning, can be referred to as self-efficacy career.

Based on a preliminary study conducted at SMKN 2 Denpasar that the implementation of group counseling has not been optimal even though it has been carried out in accordance with the existing stages. BK teachers as group leaders still use conventional methods, namely using one approach to solve problems faced by students, causing group members to tend to get bored quickly. The implementation of group counseling is also still incidental and casuistic and special methods to improve self-efficacy also do not exist so that the objectives of group counseling have not been achieved. In addition to the results of the preliminary study above, previous researchers have developed a similar model, namely in the research of Rowell, Giordano \& Kemer (in the Study et al., 2019a) the group counseling model is effective in improving student career decision making but has several limitations, namely there are three indicators in career decision making, namely lack of readiness, lack of information and inconsistent information. Among the three indicators, theindicator lack of readiness has the lowest increase value in terms of uncertainty in the career decision-making process, namely self-efficacy is still low and needs to be improved. Based on the results of Puspita's research (in Santi, 2014) it is synthesized that there are various concerns which indicate that the ability of adolescents to prepare for their careers is still low. This can be seen in various problems, both related to choosing the type of further study, choosing a job plan, as well as relating to the unpreparedness of high school and vocational school graduates in entering further education or the world of work.

The fact that SMK students have not been able to make decisions regarding choosing a university was also discussed in previous research conducted by Hayadin (in Darmasaputro \& Gunawan, 2018) and the results showed that $47.7 \%$ of students at the same level (SMA, MA, SMK) already had a choice. College and $52.3 \%$ do not have a choice of Higher Education. As many as $52.3 \%$ of these students returned the questionnaire because they did not have a choice of higher education, and the rest already had a choice. The results of research conducted by Hayadin (2006) showed that there are still many students at the SMK level who have difficulty making the right decisions regarding further studies to Higher Education.

A study conducted by Yulianto (2012) at SMA Purworejo, found the fact that grade XII students were still hesitant in choosing an education after graduating from SMK. They feel less confident in determining the next educational program because of limited information and the absence of career planning. Furthermore, Wati (in the Study et al., 2019a) shows that SMK students do not yet have a directed career plan. Around $45 \%$ of SMK students do not have a plan regarding the career they will choose, because they are still having doubts. The phenomenon at SMKN 2 Denpasar shows the low level of student career decision making. Based on the results of DCM processing on the class XII students of SMKN 2 Denpasar, on the topic of the future and educational goals/positions, $64.3 \%$ of students do not know what to do after graduating, followed by the same percentage of $60.7 \%$ of students who do not have certain goals. and their ideals are always shaky/changing.

Based on the above phenomenon, that teenagers, especially students of SMK class XII still feel unsure of their career choices and plans with their abilities, so that students experience confusion and hesitation in making decisions about their careers, joining friends or parents in making decisions about their careers. decision-making. Whereas career self-efficacy directs individuals to understand their conditions realistically, so that individuals are able to adjust between expectations for the work they want and their abilities. As a result, with this condition, some graduates from Vocational High Schools (SMK) are not optimal in choosing their careers. So researchers are motivated to develop a model of group counseling using modeling techniques. So the researchers compiled a development study with the title "Development of a Model Guide for Group Counseling Modeling Techniques to Improve Students' Self-Efficacy in Making Career Decisions for Vocational High School Students". 


\section{Method}

\section{Research Design}

This research is a type of research and development (R\&D). According to Sugiyono (in Hughes, 2008) research and development methods (Research and Development) are research methods used to produce certain products, and test the effectiveness of these products. The product developed in this study is a counseling guide with modeling techniques to increase self-efficacy in students' career decision making. The

Design of this study uses a 4D (four-D) development model. The research and development model of the 4D model consists of 4 stages, namely; define, design, develop, and disseminate (in Hughes, 2008) The 4D development model can be adapted into 4Ps, namely; definition, design, development, and deployment.

\section{Research Subject}

Subjects in this study were a group counseling guide book on modeling techniques to improve students' self-efficacy in making career decisions for vocational students. While the trial subjects for the acceptance test of this study were 3judgesor experts in the field of guidance and counseling and 2 practitioners in the field of guidance and counseling.

While the test subjects for the effectiveness of the modeling technique group counseling guidebook to improve self-efficacy in making career decisions are XI students of SMK 2 Denpasar.

\section{Research Instruments}

The instruments used or questionnaires used to collect data in this study, namely the self-efficacy questionnaire in decision-making and the acceptance questionnaire of group counseling guidance modeling techniques. The questionnaire was developed by the researcher himself.

\section{Data Analysis Procedure}

The results of filling out the instrument validation guidebook by experts were analyzed with the aim of proving the feasibility of the modeling technique group counseling guidebook. The results of responses by experts to each item on the validity test sheet of the group counseling guidebooktechnique using the content validity ratio or CVR (ModelingContent Valdity Ratio) proposed by (Lawshe, 1975)

$$
C V R=\frac{N e-\frac{N}{2}}{\frac{N}{2}}
$$

(Lawshe, 1975)

Description:

CVR : content validity ratio

$\mathrm{N}$ : number of experts

$\mathrm{n}_{\mathrm{e}}$ : number of experts who provide relevant values

The criteria for decision making are based on the results of the CVR test are as follows:

If:

$\mathrm{n}_{\mathrm{e}}<\mathrm{N}$ then CVR $<0$ (failed/invalid)

$\mathrm{n}_{\mathrm{e}}<\mathrm{N}$ then $\mathrm{CVR}=0$ (failed/invalid)

ne $>\mathrm{N}$ then $\mathrm{CVR}<0$ (accepted/valid) 
After If the CVR value is found, then the overall validity value is determined using the content validity index (CVI) using the following formula.

$$
C V I=\frac{\sum C V R}{k}
$$

(Lawshe, 1975)

Description:

CVI: content validity ratio

CVR: total content validity ratio

$\mathrm{k}$ : number ofitems

Further to test the effectiveness of using group counseling Modeling techniques for increasing self-efficacy in making student career decisions, is done by looking for an effective contribution ( $n n$ effect size) using the Cohen-D formula as follows.

$$
\text { Effect size }=\frac{\text { post test average score }- \text { pre test average score }}{\text { Standard Deviation }}
$$

\section{Results and Discussion}

Expert or expert testing the validity of the guidebook product is carried out by five (5) experts in the field of Counseling Guidance and Psychology, namely: the first expert Dr. I Ketut Gading, M.Psi in the field of Counseling Guidance, the second expert Prof. Dr. I Ketut Dharsana, M.Pd., Kons, namely Professor in Counseling Guidance; third expert Prof. Dr. Nyoman Dantes is Professor of Counseling Guidance; fourth expert Drs. I Ketut Gede Suraharja, M.Pd in the field of Counseling Guidance; fifth expert Gusti Ayu Putu Nia Antari, S.Pd. M.Pd in the field of Counseling Guidance.

The results of the above data analysis with the Lawshe CVR test obtained a per-item value between 1 to $0(\mathrm{CVR}>0)$ and there was no item with a value less than $0(\mathrm{CVR}<0)$. Lawshe, 1975) states that the CVR formula produces values with a range of +1 to -1 , a positive value indicates that half the authors rate the item as important or essential. The greater the CVR value of 0 , the more accepted and the higher the validity of the product content, so the expert judges the guidebook product as valid. Lawshe's analysis results get a score of $1(\mathrm{CVI}>0)$. These results indicate the value of the content validity of the guidebook product is high or declared valid or feasible.

To determine the level of self-efficacy in making career decisions for vocational students, it is necessary to know the level of self-efficacy of students with self-efficacy instruments in making career decisions as many as 20 questions for vocational students totaling 30 people and after distributing the efficacy instrument the themselves in making career decisions, students then look for the validity of each instrument by using the Product Moment formula.

Based on the results of the instrument validity test using the Product Moment formula by looking at the test criteria, the question criteria are in the valid category if $\mathrm{R}_{\mathrm{hit}}>$ from $\mathrm{r}_{\text {tab }}$ with a significant level of $5 \% \mathrm{~N}=$ 30 then $r_{\text {tab }}=0.361$, it is known that all items are declared valid or feasible. The $r_{\text {hit }}$ table is supported by testing the validity of the instrument using the SSPS 24 program. Next, looking for the reliability of the items to determine the consistency of the items using Cronbach's Alpha, then according to the reliability coefficient criteria $\left(\mathrm{r}_{\mathrm{xx}}\right)$ whose numbers are in the range from 0 to 1.00 . The higher the reliability coefficient close to 1.00 means the higher the reliability. On the other hand, the lower the coefficient closer to 0 means the lower the reliability. So that the results of the reliability test are declared low. 
Based on the posttest and pretest calculations above, it can calculate the effectiveness of the guidebook and get the results of 3.17 So based on the value of the effectiveness of the above then according to the criteria. If the value is effect size $>0.50$ then the group counseling guide for modeling techniques is effective to minimize self-efficacy students' in making career decisions.

\section{Conclusion}

The results of the analysis of the expert validity test of the counseling manual product modeling technique obtained an important product to be developed, which is based on the results of the content validity data analysis by the expert. The results of the data analysis above with the Lawshe CVR Test obtained a value per item (CVR $>0$ or 1) for all items, then the results of the Lawshe CVI analysis obtained a score of 1, then this result means that the value of the content validity of the product content of the group counseling guidebook Modeling technique is high. And test the validity of the instrument using the Cronbach Alpha formula by looking at the test criteria are the criteria for the question in the valid category if rhit $>$ from rtab with a significant level of $5 \% \mathrm{~N}=30$ then $\mathrm{rtab}=0.361$, it is known that 5 instrument items are declared valid and 15 instrument items are said drop or fail. The calculated table $\mathrm{r}$ is supported by testing the validity of the instrument using the SPSS 24 application. Based on the effectiveness test of the development of the guidebook in the experimental class and control class, based on the posttest and pretest calculations above, it can calculate the effectiveness of the guidebook and get results 3.17. according to the criteria. If thevalue is effect size $>0.50$ then the group counseling guide for modeling techniques is effective for minimizing self-efficacy students'in making career decisions.

\section{Acknowledgment}

Authors would like to thank and appreciate profusely for all the help, guidance, and contributions of all related parties who have worked hard for the development of this research. The authors would like to thank the supervisor of this research, Dr. I Ketut Gading, M.Psi as the first supervisor, and Prof. Dr. I Ketut Dharsana, M.Pd., Kons as the second supervisor who always provides direction in this research. Dr. Nyoman Dantes., As a validation of the experts, Drs. I Ketut Gede Suraharja, M.Pd; Gusti Ayu Putu Nia Antari, S.Pd. M.Pd., as a BK teacher who is willing to test the experts. And all related parties who have provided support for this research have achieved the expected results.

\section{References}

Abi, A. A. (2019). Student Career Maturity Level (Descriptive Study for Seventh Semester Students of Guidance and Counseling Study Program at Sanata Dharma University Batch 2014). Thesis, 1-93.

Adiputra. (2015). Group Counseling.

Andriati, N., \& Rustam, R. (2018). Development of Group Guidance Models Through Problem Solving Methods To Improve Student Learning Motivation. JBKI (Journal of Guidance Counseling Indonesia), 3(1), 11. https://doi.org/10.26737/jbki.v3i1.523

Azwar. (2010). Item Validity Test. ISSN 2502-3632 (Online) ISSN 2356-0304 (Paper) International \& National Online Journal Vol. 7 No.1, January - June 2019 Universitas 17 August 1945 Jakarta, 53(9), 1689-1699.

Guidance, J., Education, F. I., \& Ganesha, U. P. (2017). The Effectiveness of Behavioral Counseling Modeling Techniques and Transactional Analysis Counseling Role Playing Techniques to Minimize the Tendency of Aggressive Behavior of High School Students. 2(4), 157-164.

Cohen, Manion, \& Morrison. (2007). Effectiveness Test. Angewandte Chemie International Edition, 6(11), 951-952.

Darmasaputro, A., \& Gunawan, W. (2018). Relationship of Career Decision Making Self-Efficacy and Career Decision Making in High School Students. Journal of Psychology, 14(1), 1.https://doi.org/10.24014/jp.v14i1.5004

Egziabher, T. B. G., \& Edwards, S. (2013). No Title No Title. Africa's Potential for the Ecological Intensification of Agriculture, 53(9), 1689-1699. 
Fitria. (2013). No Title No Title. Journal of Chemical Information and Modeling, 53(9), 1689-1699.

Frederica, A.G. (2020). The relationship between self-efficacy and career decision making in vocational high school students (SMK). Thesis, 10-25.

Fundación Terram. (2015). No Title空間像再生型立体映像の. Nhk技研, 151, 10-17.

Ganesha, U. P. (2018). Effectiveness of Behavioral Counseling Modeling Techniques with Lesson Study Settings to Improve Self-Succorance of Class VII. 3 Students of Undiksha Singaraja Middle School Lab Introduction. 2(2), 90-96. https://doi.org/10.23887/XXXXXX-XX-0000-00 Ghufron \& Risnawati. (2017). Psychological Theories.

Heryaniningsih, S. M. (2014). The Effectiveness of Group Counseling Services in Symbolic Modeling Techniques to Overcome Disciplined Behavior in Class VIII SMP Negeri 2 Tayu, Pati Regency, 2018/201 Academic Year. 32.

Hidayatullah, D. (2018). Chapter II Theoretical Foundation. Journal of Chemical Information and Modeling, 53(9), 8-24.

Hughes, R. (2008). design research development (R\&D). Journal of Chemical Information and Modeling, 53(9), 287.

Kurniasari, RI, Dariyo, A., \& Idulfilastri, RM (2018). The Relationship Between Self-Efficacy and

LAWSHE, CH (1975). a Quantitative Approach To Content Validity. Personnel Psychology, 28(4), 563575. https://doi.org/10.1111/j.1744-6570.1975.tb01393.x

Nadiana, K. (2014). Application of Super Career Guidance with Modeling Techniques to Improve Career Decision Planning in Class IX B5 SMP N 4 Singaraja Students. E-Journal Undiksa Counseling Guidance Department, 2(1).

Santi, DEP (2014). Application of Trait and Factor Career Counseling Developing Career Choice Plans for Class X Tpm 1 Smk Negeri 3 Singaraja Students. Undiksa Department of Counseling Guidance, 2 No 1,(1).

Study, P., Dan, B., \& Semarang, UN (2019). Model Development of Modeling Techniques Group Counseling. 3..

Article Information (Supplementary)

Conflict of Interest Disclosures:

The authors declare that they have no significant competing financial, professional or personal interests that might have influenced the performance or presentation of the work described in this manuscript.

Copyrights Holder: <mutmaina $><2021>$

First Publication Right: BISMA The Journal of Counseling

https://doi.org/10.xxxx/ $\mathbf{x x x x x}$

Open Access Article | CC-BY Creative Commons Attribution 4.0 International License. 